\title{
Congenital tracheomalacia
}

INSERM

\section{Source}

INSERM. (1999). Orphanet: an online rare disease and orphan drug data base. Congenital tracheomalacia. ORPHA:95430

Cong enital tracheomalacia is a rare condition where the trachea is soft and flexible causing the tracheal wall to collapse when exhaling, coughing or crying, that usually presents in infancy, and that is characterized by stridor and noisy breathing or upper respiratory infections. Tracheomalacia improves by the age of 18-24 months. 